\title{
Glaciers and their contribution to sea level change
}

\author{
Roger J. Braithwaite ${ }^{\mathrm{a}, *}$, Sarah C.B. Raper ${ }^{\mathrm{b}}$ \\ a School of Geography, The University of Manchester, Oxford Road, Manchester M13 9PL, UK \\ b Alfred Wegener Institute for Polar and Marine Research, Bremerhaven D-27515, Germany
}

\begin{abstract}
Increased melting of glaciers and ice caps, excluding Greenland and Antarctica, will probably represent the second largest contribution to global sea level rise by 2100 . The temperature sensitivity of sea level rise depends upon the global distribution of glacier areas, the temperature sensitivity of glacier mass balance in each region, the expected change of climate in each region, and changes in glacier geometry resulting from climate change. None of these are particularly well known at present. Improvements in global climate models should eventually give better information about expected climate changes in regions where glaciers occur but there is also much work for glaciologists. For example, glacier areas, altitudes, shape characteristics and mass balance sensitivity are still not known for many glacierized regions and ways must be found to fill gaps.
\end{abstract}

(C) 2002 Elsevier Science Ltd. All rights reserved.

Keywords: Glaciers; Ice caps; Sea level; Climate change; Mass balance

\section{Introduction}

Charles MacLaren (1782-1866) was the first person to state a relation between changes in terrestrial ice masses and sea level variations in an 1842 article in The Scotsman newspaper (Imbrie and Imbrie, 1979). Modern discussions of climate change always give prominence to possible rises in sea level as a major impact, and the spectre of those "melting polar ice caps" is alive and well in the popular imagination. Projections of future sea level under a warmer climate, giving due prominence to glaciers and ice sheets, were stimulated by a workshop held in 1984 in Seattle (Polar Research Board of the National Research Council, 1985). In particular, the role of mountain glaciers and ice caps, i.e. excluding the great ice sheets, was described in a seminal paper by Meier (1984) that has set the agenda for later work.

Concerns about climate change lead to the establishment of the Intergovernmental Panel on Climate Change (IPCC) in the late 1980's to assess climate research and thereby help policy formulation at the international level. Three scientific assessments by the IPCC include up-to-date reviews of sea level research and future projections by Warrick and Oerlemans

\footnotetext{
${ }^{*}$ Corresponding author. Tel.: + 44-161-275-3644; fax: +44-161-2757878.

E-mail address: r.braithwaite@man.ac.uk (R.J. Braithwaite).
}

(1990), Warrick et al. (1996) and Church et al. (2001). The last can be regarded as representing the present "state of the art". According to Church et al. (2001), average global sea level may rise by $0.09-0.88 \mathrm{~m}$ by the year 2100 . This range of values expresses the uncertainty due to different emissions scenarios, different climate models and different sensitivities of ice volume to climate change. Sea level projections are made in terms of separate contributions from different sources because of the different processes involved. The different sources are thermal expansion of the seawater itself $(0.27 \mathrm{~m}$ sea level rise by 2100) and changes in the land based cryosphere as well as changes in terrestrial storage (Church et al., 2001, Table 11.14). The cryospheric changes include changes in (1) mountain glaciers and ice caps $(0.12$ $\mathrm{m}$ sea level rise), (2) the Greenland ice sheet $(0.04 \mathrm{~m})$, and (3) Antarctica (0.08 m).

The purpose of our paper is to briefly review progress in the area up to 2001 and to sketch our ongoing work. We only deal with the contribution to sea level rise from mountain glaciers and ice caps, which will be the major cryospheric contributor to the year 2100. Although the general term "glacier" includes "ice sheet" (Armstrong et al., 1973), we essentially exclude the Greenland and Antarctic ice sheets in our use of "glacier" in the present paper.

As projections of future sea level depend upon the chosen climatic scenario, as well as the chosen time scale 
for the projection, it is difficult to compare projections. We therefore focus on the temperature sensitivity of global sea level rise to increased melting of glaciers and ice caps. This means that we consider the immediate effect of $\mathrm{a}+1 \mathrm{~K}$ temperature increase, and are not tied to any particular scenario of climate change. The "state of the art" is such that hardly anyone would actually make a sea level projection with such a global sensitivity but it is a valuable quantity to calculate for comparing different estimates, e.g. as done in the 2001 IPCC report (Church et al., 2001).

\section{Glacier mass balance and global sea level}

The relationship between glaciers, climate and sea level can be illustrated by the general equation:

$\mathrm{SLR}=-\left(1 / A_{0}\right) \sum_{r=1}^{r=R} S_{r} \underline{b}_{r}$

where SLR is the global average sea level rise $\left(\mathrm{m} \mathrm{a}^{-1}\right)$ due to melting of glaciers and ice caps and $\underline{b}_{r}$ is the glacier mass balance $\left(\mathrm{ma}^{-1}\right)$ in the $r$ th region with a glacier area of $S_{r}\left(\mathrm{~km}^{2}\right) . R$ is the total number of glacierized regions in the world and $A_{0}$ is the total area of the oceans $\left(\mathrm{km}^{2}\right)$. The minus sign in (1) is necessary because a decrease in mass balance corresponds to an increase in sealevel rise. The sensitivity of SLR to temperature change is given by

$\Delta \mathrm{SLR} / \Delta T_{\mathrm{G}}=-\left(1 / A_{0}\right) \sum_{r=1}^{r=R} S_{r}\left(\Delta \underline{b}_{r} / \Delta T_{r}\right)\left(\Delta T_{r} / \Delta T_{\mathrm{G}}\right)$

where $\Delta \mathrm{SLR} / \Delta T_{\mathrm{G}}$ is the sensitivity of SLR $\left(\mathrm{m} \mathrm{a}^{-1} \mathrm{~K}^{-1}\right)$ to change in global temperature $T_{\mathrm{G}} . \Delta \underline{b}_{r} / \Delta T_{r}$ is the sensitivity of glacier mass balance $\left(\mathrm{m} \mathrm{a}^{-1} \mathrm{~K}^{-1}\right)$ in the $r$ th region to temperature changes $\Delta T_{r}$ in the region. $\Delta T_{r} / \Delta T_{\mathrm{G}}$ is the sensitivity of regional temperature to changes in global temperature $\Delta T_{\mathrm{G}}$. The regional temperature $T_{r}$ on the RHS of (2) is the kind of temperature that might appear on a weather map or might be found in a regional climatology, i.e. it is outside the direct influence of the glacier. The temperature actually measured at $2 \mathrm{~m}$ above a glacier surface is somewhat colder than the equivalent altitude regional temperature due to operation of a "glacier cooling effect" (Braithwaite, 1980; Greuell and Böhm, 1998). The calculation of the sensitivity of mass balance to changes in regional temperature $\left(\Delta \underline{b}_{r} / \Delta T_{r}\right)$ must include a link between local and regional temperatures.

Eq. (3) defines the mass balance of a single glacier, termed the mean specific balance, as the area-weighted mean of the mass balances (specific balances) for different parts of the glacier:

$\underline{b}_{0}=(1 / S) \sum_{i=1}^{i=N} b_{0, i} s_{i}$ where $\underline{b}_{0}$ is the mean specific net balance of a glacier under the reference climate state denoted by " 0 ". The mass balance at the $i$ th altitude band on the glacier is $b_{0, i}, s_{i}$ is area of the $i$ th altitude band and $N$ is the number of such bands. The total area of the whole glacier is $S$. Mass balance generally depends on altitude with negative balances at lower altitudes and positive balances at higher altitudes. This reflects decreased melting with increasing altitude and decreasing temperature, and increased snow accumulation with altitude. The relation between mass balance and altitude is generally curvilinear with many deviations due to local effects of topography, exposition, and variations in accumulation, including effects of snow drift.

The sensitivity of glacier mass balance to regional temperature change is given by

$\Delta \underline{b} / \Delta T_{r}=(1 / S) \sum_{i=1}^{i=N}\left(\left(b_{1, i}-b_{0, i}\right) / \Delta T_{r}\right) s_{i}$

where $b_{1, i}$ and $b_{0, i}$ refer to specific balances at the $i$ th altitude for climates 1 and 0 separated by $\Delta T=1 \mathrm{~K}$. The sensitivity in (4) is defined as the response to a $1 \mathrm{~K}$ temperature rise from a reference state because the relation between mass balance and temperature is somewhat non-linear (Oerlemans and Hoogendoorn, 1989; Oerlemans, 1993; Braithwaite and Zhang, 1999). Eq. (4) states that the mass balance sensitivity of the whole glacier (of area $S$ ) is the area-weighted average of the sensitivity at each altitude. The temperature sensitivity in (4) could refer to "temperature change with all other variables held constant" or to "temperature changes with associated changes in all other variables" and can be for temperature changes operating over the whole year or only for a specific season. In principle, as the area distribution changes, the temperature sensitivity must also change.

If (3) and (4) are applied to the mass balance in a particular year, the glacier area $\mathrm{S}$ can be treated as constant for that year. However, glacier areas are not constant over many decades and estimation of change in glacier areas is an active research topic. Oerlemans and Fortuin (1992), Oerlemans (1993), Zuo and Oerlemans (1997) and Gregory and Oerlemans (1998) use similar equations to (2) but neglect variations in glacier area. Van de Wal and Wild (2001) take account of changing glacier areas but neglect the change of mean mass balance with area. In (4) the largest balance changes will occur at lower altitudes where most of the main shrinkage of area occurs, which means that the mass balance sensitivity for the whole glacier must be reduced as the area shrinks.

We can make an order-of-magnitude estimate of the global sea level sensitivity by drastically simplifying (2) to:

$\Delta \mathrm{SLR} / \Delta T_{\mathrm{G}}=-\left(1 / A_{0}\right) A_{\text {Glaciers }}\left(\Delta b / \Delta T_{\mathrm{G}}\right)$ 
Table 1

Global sea level sensitivity for five different scenarios of mass balance sensitivity applied to all mountain glaciers and ice caps, excluding Greenland and Antarctic

\begin{tabular}{llll}
\hline $\begin{array}{l}\text { MB Sensitivity } \\
\left(\mathrm{m} \mathrm{a}^{-1} \mathrm{deg}^{-1}\right)\end{array}$ & $\begin{array}{l}\text { Global glacier area, Sea level } \\
\text { sensitivity }\left(\mathrm{mm} \mathrm{a}^{-1} \mathrm{deg}^{-1}\right)\end{array}$ \\
\cline { 2 - 4 } & & $0.52 \times 10^{6} \mathrm{~km}^{2}$ & $0.68 \times 10^{6} \mathrm{~km}^{2}$ \\
\hline Very low & -0.2 & 0.3 & 0.4 \\
Low & -0.4 & 0.6 & 0.8 \\
Medium & -0.6 & 0.9 & 1.1 \\
High & -0.8 & 1.2 & 1.5 \\
Very high & -1.0 & 1.5 & 1.9 \\
\hline
\end{tabular}

Calculations made for two different estimates of global glacier area. The higher value $\left(0.68 \times 10^{6} \mathrm{~km}^{2}\right)$ from Dyurgerov and Meier (1997) may be more correct but only about $0.52 \times 10^{6} \mathrm{~km}^{2}$ are presently localised within $1^{\circ}$ of latitude and longitude.

where $A_{\text {Glaciers }}$ is the total area of glaciers in the world. In this case, we assume uniform temperature change $\left(\Delta T_{r} / \Delta T_{\mathrm{G}}=1\right)$ and mass balance sensitivity for the whole world. Some results are given in Table 1 for a range of mass balance sensitivity. The calculation is made for two different estimates of global glacier cover, i.e. 0.52 and $0.68 \times 10^{6} \mathrm{~km}^{2}$. The resulting range of sea level rise is about $0.3-1.5$ (or $0.4-1.9$ ) $\mathrm{mm} \mathrm{a}^{-1} \mathrm{deg}^{-1}$. This represents the range of uncertainty caused by not knowing which mass balance sensitivity to use.

The regional approach of (2) attempts to take account of differences in mass balance sensitivity between different regions, reflecting effects of different climates, and should reduce this uncertainty. The use of two different areas for global glacier cover in the above calculation should alert the reader to uncertainties about global glacier cover, which are discussed in Section 3.

Eqs. (1)-(5) illustrate the fact that we need to know more about the following:

(i) geographical distribution of glaciers in the world with respect to areas and types, (ii) climatic conditions in glacial regions,

(iii) glacier mass balance as functions of altitude in different regions.

As any change in mass balance results in a changing glacier area and mass balance sensitivity, we also need to know more about:

(iv) changes in glacier geometry.

We briefly review these problems and sketch our ongoing work but we do not suggest that they will be solved easily or quickly. Satisfactory solutions of (i)-(iv) will probably take a decade of work by many different groups in a number of disciplines.

\section{Global distribution of glaciers}

There is still not complete agreement about the total global area of glaciers and ice caps and some recent estimates are listed in Table 2. The figures in column (c) are based on the 100 regions of Oerlemans (1993) and are still the basis for the IPCC 2001 report (Church et al., 2001). In our present work we use the GGHYDRO 2.2 dataset from Trent University, Canada (Cogley, 1998) because this is a gridded dataset $\left(1^{\circ} \times 1^{\circ}\right.$ grid $)$ which can be easily related to other gridded datasets. The GGHYDRO dataset lists the percentage of glacier cover in each $1^{\circ}$ grid square. Excluding Greenland and Antarctica, there are 848 cells with at least 1 percent cover of mountain glaciers and ice caps (Fig. 1). There are, however, some areas with too little glacier cover $(<1$ percent) to appear in the dataset. These include Labrador, Pyrenees, Polar Ural, East Africa and western New Guinea (Irian Jaya) where small glaciers occur. The GGHYDRO dataset, column (d) Table 2, gives a slightly smaller global total for glacier area than Meier (1984) and Haeberli et al. (1989) but is not very different from the area distribution used by Oerlemans and Fortuin (1992) and Oerlemans (1993). The general

Table 2

Global distribution of glaciers areas according to different sources: (a) Meier (1984); (b) Haeberli et al. (1989); (c) Oerlemans (1993); (d) our work using data from Cogley (1998); (e) Dyurgerov and Meier (1997), quoting Weidick and Morris (1998)

\begin{tabular}{|c|c|c|c|c|c|}
\hline Region & (a) $\left(\mathrm{km}^{2}\right)$ & (b) $\left(\mathrm{km}^{2}\right)$ & (c) $\left(\mathrm{km}^{2}\right)$ & (d) $\left(\mathrm{km}^{2}\right)$ & (e) $\left(\mathrm{km}^{2}\right)$ \\
\hline N. America (Arctic) & 150,600 & 151,758 & 149,900 & 153,184 & \\
\hline N. America (Mainland) & 125,210 & 124,342 & 109,680 & 101,505 & \\
\hline S. America & 36,250 & 25,908 & 36,298 & 31,521 & \\
\hline Greenland (Local glaciers) & & & & & 70,000 \\
\hline Iceland & 11,300 & 11,260 & 10,938 & 11,160 & \\
\hline Svalbard & 38,800 & 36,612 & 36,612 & 33,685 & \\
\hline W. Europe (Mainland) & 6000 & 6095 & 5625 & 6758 & \\
\hline Africa & & 10 & 11 & & \\
\hline Arctic Eurasia & 56,100 & 56,135 & 55,696 & 60,723 & \\
\hline Former USSR + Asia & 111,900 & 129,076 & 117,129 & 121,711 & \\
\hline Australasia & 1000 & 860 & 1007 & 433 & \\
\hline Sub-antarctic & 5000 & 7000 & 5000 & 2646 & \\
\hline Antarctic (Local glaciers) & & & & & 70,000 \\
\hline Excluding ice sheets & 542,160 & 549,056 & 527,896 & 523,326 & 680,000 \\
\hline
\end{tabular}




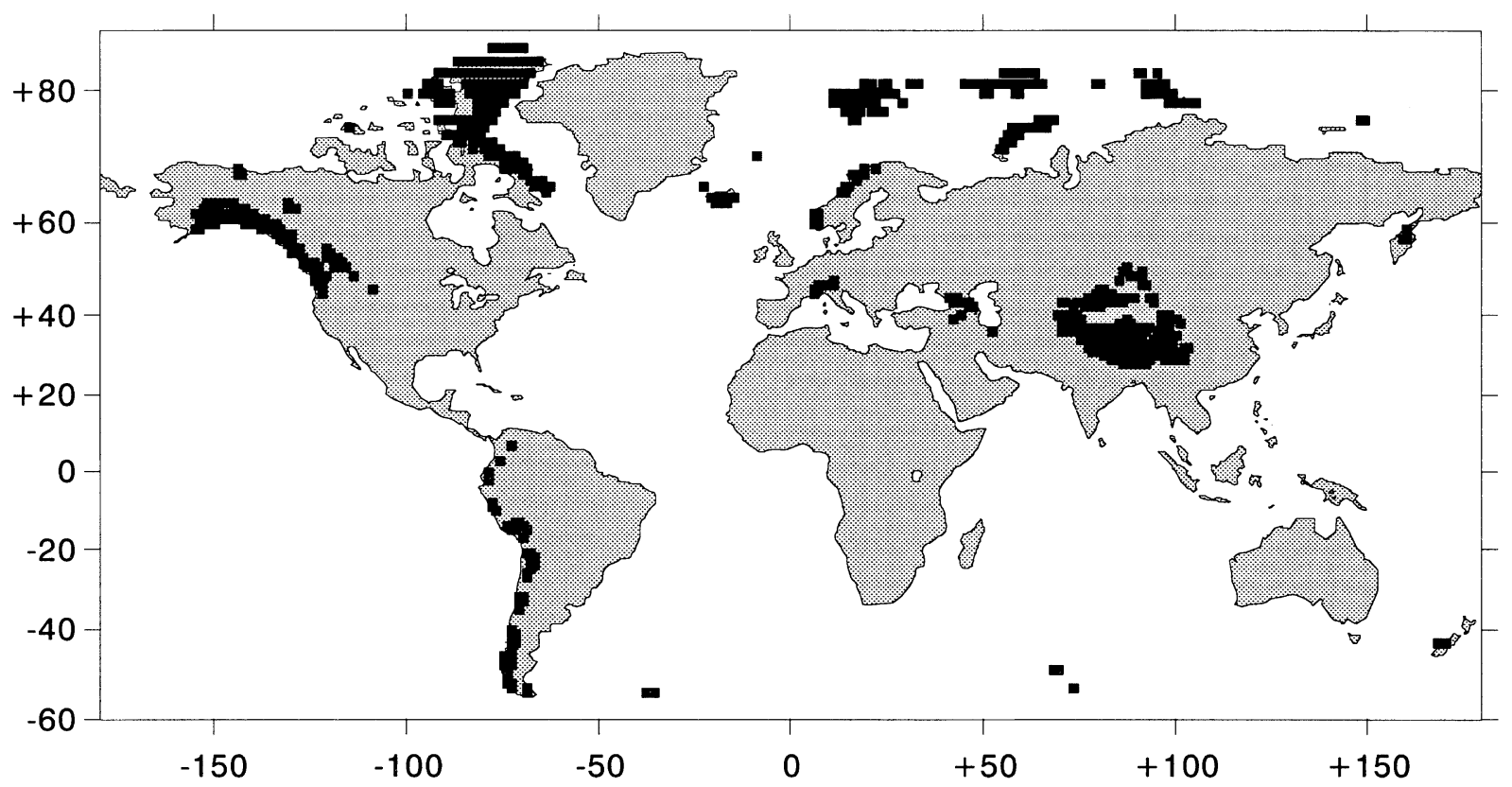

Fig. 1. Locations of all areas with glaciers and ice caps excluding Greenland and Antarctica. Based on the $1^{\circ}$ GGHYDRO 2.2 gridded glaciology (Cogley, 1998). Grid squares with a glacier cover of less than about $20 \mathrm{~km}^{2}$ are not included. Figure reproduced from Braithwaite (2002) by permission of Edward Arnold Publishers.

agreement between these different sources does not necessarily mean that the global distribution of glaciers is well known, as the different sources must be based on essentially the same kind of information.

Very high quality glacier inventories are available for some regions from the World Glacier Inventory (WGI) (WGMS, 2000) and ought to give the best estimate of glacier area for those regions but large areas are still uncovered. One problem with WGI data is that "absence of evidence is not evidence of absence" as there is no simple way of denoting "missing data" for areas where glaciers occur but are unregistered. Glacier areas according to the GGHYDRO 2.2 dataset and WGI (WGMS, 2000) datasets are compared in Table 3. The areas of individual glaciers from the WGI have been summed to give totals for $1^{\circ}$ grid squares where glaciers occur. The GGHYDRO 2.2 dataset covers 837 grid squares $\left(1^{\circ} \times 1^{\circ}\right)$ while the WGI presently only covers 524 grid squares. However, this latter figure includes
273 grid squares (Case 1) that have no glacier area according to the GGHYDRO 2.2 dataset, presumably because the glaciers are too small and scattered to appear on the base maps. The resolution of GGHYDRO 2.2 is such that glacier covers of less than about $20 \mathrm{~km}^{2}$ per grid square do not appear while the resolution of the WGI is different in different parts of the World. In the Alps, the smallest inventoried glaciers are about $0.03 \mathrm{~km}^{2}$ while the cutoff for Svalbard is $1 \mathrm{~km}^{2}$ according to Meier and Bahr (1996) who advocate the use of scaling methods to fill gaps in the global data. In Case 2, GGHYDRO indicates the presence of glaciers, which might not be entirely accurate, but the data are missing from WGI. Presumably, there really are glaciers in most, if not all, of these grid squares but the glacier inventory has not been completed. Even where the two datasets agree on the presence of glaciers (Case 3) there are still large differences in total glacier area.

Table 3

Comparison of glacier areas according to the $1^{\circ}$ gridded glaciology (GGHYDRO) and the WGI, excluding Greenland and Antarctica

\begin{tabular}{|c|c|c|c|c|c|}
\hline \multirow[t]{2}{*}{ Case } & \multirow[t]{2}{*}{ Glacier area in $1^{\circ}$ grid squares } & & \multirow[t]{2}{*}{ Number of $1^{\circ}$ grid squares } & \multicolumn{2}{|c|}{ Total area $\left(\mathrm{km}^{2}\right)$} \\
\hline & & & & GGHYDRO & WGI \\
\hline 1 & $\begin{array}{l}\text { Glacier area }=0 \text { according } \\
\text { to GGHYDRO }\end{array}$ & $\begin{array}{l}\text { Glacier area }>0 \\
\text { according to WGI }\end{array}$ & 273 & 0 & 22,302 \\
\hline 2 & $\begin{array}{l}\text { Glacier area }>0 \text { according } \\
\text { to GGHYDRO }\end{array}$ & $\begin{array}{l}\text { Glacier area }=0 \\
\text { according to WGI }\end{array}$ & 586 & 345,340 & 0 \\
\hline \multirow[t]{2}{*}{3} & $\begin{array}{l}\text { Glacier area }>0 \text { according } \\
\text { to GGHYDRO }\end{array}$ & $\begin{array}{l}\text { Glacier area }>0 \\
\text { according to WGI }\end{array}$ & 251 & 177,707 & 117,723 \\
\hline & Total & & 1110 & 523,047 & 140,025 \\
\hline
\end{tabular}


Early work on glaciers and sea level ignored the many mountain glaciers and ice caps in the Antarctic and Greenland that are not directly connected to the ice sheet ("local" glaciers). Several authors quote Weidick and Morris (1998) as giving the total area of 140,000 $\mathrm{km}^{2}$ for these ice masses but not in a digital form. In our ongoing work, we follow Oerlemans (1993) in excluding these local glaciers from sea level models because their geographical co-ordinates are not accurately known and cannot be included in regional models.

Sea level sensitivities for the lower estimate of global glacier area $\left(0.53 \times 10^{6} \mathrm{~km}^{2}\right)$ used by Oerlemans $(1993)$ could be scaled to the area of about $0.68 \times 10^{6} \mathrm{~km}^{2}$ (Meier and Bahr, 1996; Dyurgerov and Meier, 1997) to include the missing local glaciers in Greenland and the Antarctic. This assumes that the average mass balance sensitivity for the missing glacier area is the same as the average sensitivity for known glacier areas, which is open to question. Van de Wal and Wild (2001) estimate that the local glaciers in Greenland only add about 6 percent to the global sea level rise despite increasing the global area of glaciers and ice caps by 28 percent. This low estimate arises because they assign low precipitation to the glacier areas that they get from their digitisation of a map given by Weidick and Morris (1998). It is true that local glaciers and ice caps in north Greenland have low precipitation but the Sukkertoppen, Julianehåb, Ammassalik and Blosseville ice caps (Weidick and Morris, 1998, Fig. 12.3) must have very high precipitation and therefore high mass balance sensitivity (see below). To add to the confusion, Oerlemans (2001) extends his earlier list of 100 glacier regions (Oerlemans, 1993) by the addition of $150,000 \mathrm{~km}^{2}$ of local glaciers in north-east Greenland (coinciding roughly with Flade Isblink). With respect to Antarctica, it is probably not justified to totally neglect melting on local glaciers (Church et al., 2001) as the figure of $70,000 \mathrm{~km}^{2}$ for local glaciers in Antarctica, quoted from Weidick and Morris (1998), obviously refers to the kind of glacier judged to be liable to melt. Weidick and Morris (1998) actually give a much higher figure of $680,000 \mathrm{~km}^{2}$ for all local glaciers in Antarctica. It would be safest to regard the issue of local glaciers in Greenland and Antarctica as still open in the hope that the future work suggested by Weidick and Morris (1998) can be done.

The poor area coverage of the WGI shows that the original intentions of the WGI (Müller et al., 1977) have not yet been achieved. One can understand that relatively poor countries in South America might have difficulties but there are also large gaps in the USA and Canada although the coast of Alaska and British Columbia will be a major source of sea level rise under a warmer climate. If we only needed gridded glacier areas, a more refined version of GGHYDRO at higher resolution, possibly by remote sensing, would be adequate. However, for modelling mass balance (Section 5) we need data on both glacier area and altitude, and for modelling glacier dynamics and/or geometrical changes (Section 6) we need information on glacier geometry within different regions. These are information that would be given by a "preliminary glacier inventory" (Scherler, 1983) but even this is not accomplished yet for all areas. The activities of the Global Land Ice Measurements from Space programme (GLIMS, 2000) may facilitate progress here.

\section{Climatic conditions in glacial regions}

Increased concern about climate change in recent years has stimulated the development of several global climatologies, which include the major mountain areas where glaciers are located. For example, the $0.5^{\circ} \times 0.5^{\circ}$ gridded climatology of New et al. (1999) contains monthly values of air temperature and precipitation, and other elements, for all grid points on land. Temperature and precipitation data can be associated with individual glacier regions by locating the $0.5^{\circ} \times 0.5^{\circ}$ grid squares in which the region lies and assuming that the climatic data represent the "regional climate" just as Oerlemans and Fortuin (1992) did with climatic maps.

Gridded climatic datasets involve a number of problems (Briggs and Cogley, 1996; Hulme and New, 1997; Jones et al., 1997) and cannot be regarded as perfectly accurate. Precipitation is notoriously difficult to measure correctly, especially when it falls in the form of snow (Yang et al., 1999). Furthermore, glaciers are found at relatively high altitudes where climate stations are sparse so that global climate datasets are biased to lower altitudes. Frei and Schär (1998) have developed a high-resolution precipitation climatology for the Alps but this has not been attempted for other mountain regions, and may not even be possible for most regions.

Regional temperature and precipitation can be transferred from the $0.5^{\circ} \times 0.5^{\circ}$ gridded climatology to $1^{\circ} \times 1^{\circ}$ glacier area grid (see Section 3 ) by re-sampling. The climatology and glacier area datasets have slightly different topographic masks so that climatic data are missing for some $1^{\circ}$ grid squares close to coasts. Even if the gridded climatic data are regarded as accurate enough, the mean altitudes of their grid squares is hundreds, or sometimes thousands, of metres below the mean altitudes of the glaciers in the same grid squares. Grid temperature can be reduced to glacier altitude, if known, with a suitable lapse rate. Lapse rates in the Arctic have a strong seasonal variation but the height differences between glaciers and grid squares are small for such areas so use of a constant lapse rate is relatively unproblematic.

Projections of future sea level rise using Eq. (2) require information on climate changes in mountain areas. This is a major area of research for various groups using global climate models (GCMs) and high resolution 
limited area models. Archived results from a number of GCMs are presented by the MAGICC/SCENGEN computer program (Hulme, 2000) and are available through the IPCC Data Distribution Centre (IPCC, 2000). None of these archived results are at resolutions as high as $0.5^{\circ}$ but higher resolutions can be expected in the future, e.g. the ECHAM4 model with $1.1^{\circ}$ resolution (Schneeberger et al., 2001; Van de Wal and Wild, 2001). Papers by Zuo and Oerlemans (1997) and Gregory and Oerlemans (1998) demonstrate the possibilities of inputting regionally and seasonally differentiated climate data into glacier-climate models as described by Eq. (2). The first paper refers to historical climate changes since 1865 while the second paper refers to climate projections from a GCM. Van de Wal and Wild (2001) extend the work of Gregory and Oerlemans (1998) with a higher resolution GCM and add a volume change model. In all cases, the mass balance sensitivity is still based on the 100 glacier regions of Oerlemans (1993).

\section{Glacier mass balance}

Systematic studies of mass balance variation from year to year have been made on a number of glaciers since 1945 . However, despite much hard work by fieldworkers, data are available for many fewer than 300 glaciers (Dyurgerov and Meier, 1997; Cogley and Adams, 1998; Braithwaite, 2002; Dyurgerov, 2002). The mass balance measurements are geographically biased (Western Europe, North America and the Former USSR) and biased towards wetter conditions than the global average (Braithwaite, 2002).

In principle, it should be possible to calculate the present contribution to sea level rise from glaciers and ice caps by averaging observed mass balance data according to Eq. (1) although records of fewer than 300 glaciers, biased in various ways, is an uncertain basis for this. Even a modest imbalance of $-0.2 \mathrm{~m} \mathrm{a}^{-1}$ averaged over all glaciers in the world would give a global sea level rise of $0.3-0.4 \mathrm{~mm} \mathrm{a}^{-1}$. Dyurgerov and Meier (2000) compare average mass balances for 1961-1976 and 1977-1997 and infer a temperature sensitivity of $-0.37 \mathrm{~m} \mathrm{a}^{-1} \mathrm{~K}^{-1}$ for global glacier mass balance. This is remarkably close to global mass balance sensitivity estimated by Oerlemans (1993).

As it stands, Eq. (2) involves not only the sensitivity of mass balance to regional temperature but also the sensitivity of regional temperature to global temperature $\left(\Delta T_{r} / \Delta T_{\mathrm{G}}\right)$. The equation can be simplified by setting $\Delta T_{r} / \Delta T_{\mathrm{G}}=1$. This is equivalent to calculating the sealevel sensitivity to a globally uniform temperature change as done by Oerlemans (1993):

$\Delta \mathrm{SLR} / \Delta T_{\mathrm{G}}=-\left(1 / A_{0}\right) \sum_{r=1}^{r=R} S_{r}\left(\underline{b}_{r} / \Delta T_{r}\right)$
Eq. (6) still describes a regional approach insofar as mass balance sensitivity is estimated for each region and aggregated to give the global figure. Meier (1984) assumed that glaciers and ice caps occur in 31 different regions of varying area but he could only identify 25 glaciers with long-term data in 13 out of the 31 regions, and had to estimate glacier mass balances indirectly in the other 18 regions. This involved assuming a relation between glacier mass balance and mass balance amplitude, which can be roughly estimated for different regions by its analogy with precipitation even if mass balance cannot be similarly estimated. Braithwaite and Zhang (1999) show that mass balance sensitivity does increase (negatively) with increasing amplitude.

Meier (1993) says that the problem is in "trying to obtain a global value of mass balance (ice wastage) from a data set that is sparse geographically". Among other things, he suggests that hydro-meteorological models for individual glaciers should be "extended" using global climatic data, so that the huge areas without observational mass balance data can be included. Oerlemans and Fortuin (1992) and Oerlemans (1993) take this approach by applying a glacier-climate model to 100 glaciological regions. Their model is obtained by (1) determining the static sensitivities of 12 glaciers by energy balance modelling, (2) expressing the resulting sensitivities as a (logarithmic) function of precipitation, and (3) estimating the mass balance sensitivity of each of the 100 glacierized regions from its estimated precipitation. Oerlemans and Fortuin (1992) and Oerlemans (1993) base the areas of their glacier regions on data from the World Glacier Monitoring Service (Haeberli et al., 1989) and estimate precipitation for the 100 regions from climate maps.

In our recent work, submitted in the form of two papers to an international journal but still under review, we follow the same philosophy as Oerlemans (1993) but differ in details and sources of data. We apply the degree-day model to 61 glaciers, as an extension of the work of Braithwaite and Zhang (1999), and use regional precipitation from the gridded climatology of New et al. (1999) to estimate mass balance sensitivity for the $1^{\circ} \times 1^{\circ}$ gridded glaciers areas from Cogley (1998). Despite using different models (energy balance or degreeday) and different glaciers (12 or 61), we get a very similar relation between mass balance sensitivity and glacier precipitation (Fig. 2) to that found by Oerlemans (1993). In both cases, the glacier precipitation is calculated as part of the tuning of the mass balance model and is not greatly affected by any initial choice of precipitation from a map or climatology. This is an encouraging result as the increasingly sophisticated studies of Zuo and Oerlemans (1997), Gregory and Oerlemans (1998), and Van de Wal and Wild (2001) are all built on the same relation between mass balance sensitivity and precipitation (Oerlemans, 1993) applied to the same 100 


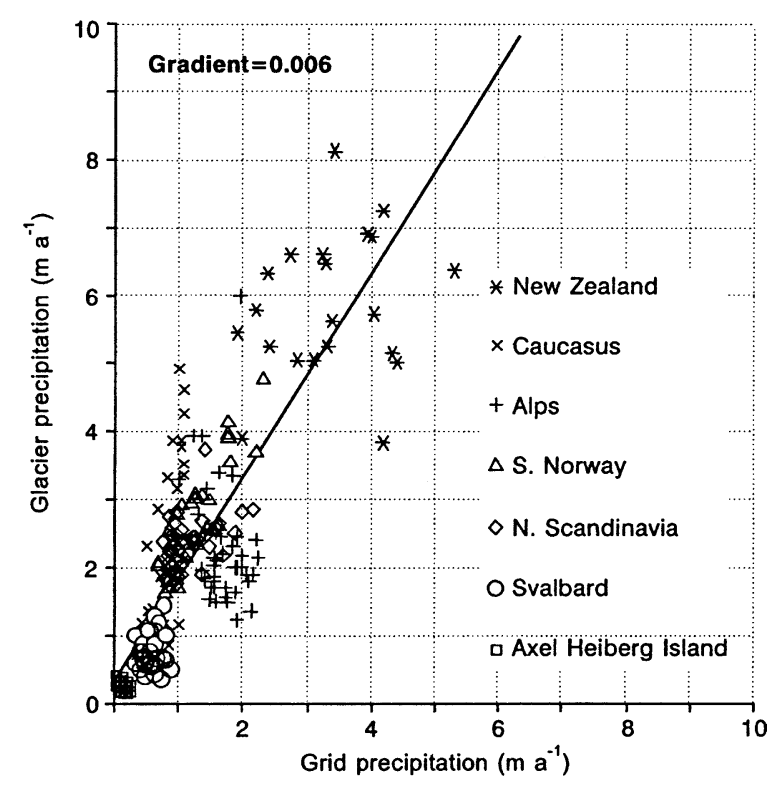

Fig. 2. Mass balance sensitivity for 61 glaciers versus glacier precipitation compared with a curve for the 12 glaciers studied by Oerlemans (1993). Results for the 61 glacier are calculated with a degree-day model based on Braithwaite and Zhang (1999). Results for the 12 glaciers provided by Oerlemans (personal communication).

glacier regions. The good agreement between the two curves in Fig. 2 does not mean that all problems are solved. There is, for example, large scatter at high precipitation so that the apparent "flattening" of the sensitivity-precipitation curve could be an artefact and further work on very maritime glaciers is needed.

The global average of mass balance sensitivity for our still unpublished study is $-0.41 \mathrm{~m} \mathrm{a}^{-1} \mathrm{~K}^{-1}$ compared with $-0.39 \mathrm{~m} \mathrm{a}^{-1} \mathrm{~K}^{-1}$ from Oerlemans (1993). Both these figures, from glacier climate modelling, are remarkably close to the Dyurgerov and Meier (2000) figure of $-0.37 \mathrm{~m} \mathrm{a}^{-1} \mathrm{~K}^{-1}$ which is based on averaging global mass balance data for two periods with different global mean temperature.

\section{Changes in glacier geometry}

If the glacier areas in Eqs. (1) and (5) are assumed constant over 1 year, Eq. (2) refers to the relation between global sea level and the static sensitivity of glacier mass balance. The equation correctly describes the instantaneous change in sea level resulting from a temperature change. However, it is more problematic to integrate the equation over a period with sustained temperature increase, i.e. over many decades as done by Van de Wal and Wild (2001), as melting increases preferentially at lower altitudes so the glacier tends to retreat up the mountain. A new equilibrium glacier configuration is then established at a higher mean/median elevation with a smaller area. The glacier surface will also sink due to increased melt, bringing any par- ticular point on the glacier surface to a lower elevation with warmer climate, thus increasing the melt as part of a positive feedback loop. It is necessary to consider the dynamic response of glaciers to capture these changes in glacier geometry (areas and altitudes).

Studies are now attempting to model the dynamic as opposed to static sensitivity (Jóhannesson, 1997; Oerlemans et al., 1998; Huybrechts and de Wolde, 1999; Schneeberger et al., 2001). The dynamic sensitivity is initially the same as the static sensitivity but, as the glacier area shrinks, the dynamic sensitivity diverges from the static sensitivity. For 12 glaciers, Oerlemans et al. (1998) say that neglecting the contraction of glacier area leads to a 25 percent overestimation of total melt by 2100. The challenge for the dynamic approach is to move from satisfactory models for individual glaciers to the behaviour of thousands of glaciers scattered throughout the world with different size and shape characteristics. As an alternative to an explicit dynamic model, Raper et al. (1996) and Raper et al. (2000) used geometric models based on scaling parameters (Bahr et al., 1997) to model individual glaciers. Van de Wal and Wild (2001) extend the approach to the global scale.

IPCC 2001 report (Church et al., 2001; Van de Wal and Wild, 2001) attempts to take account of changing glacier area but the effect of the changing area on mass balance is still neglected. According to (3) and (4) the mass balance and its sensitivity change with the glacier area distribution. We made a test calculation of the latter effect by applying model results from Braithwaite and Zhang (2000) to different area distributions for Griesgletscher (Funk et al., 1996). Results in Table 4 show what happens if the same mass balance curve (averaged for 1961-1994) is applied to different area distributions. The glacier area shrinks by 21 percent in the period 1923-1991 and the negative mass balance is greatly reduced. However, the mass balance sensitivity is only reduced by 9 percent and the mass balance amplitude is reduced by even less. This example suggests a less-than-proportionate relation between area reduction and sensitivity but is worth further investigation. One approach is to associate the mean mass balance of the whole glacier with the "representative point" of Raper et al. (1996). The height of this point is given in Table 4, measured from the maximum altitude of the glacier that is assumed constant as the glacier area shrinks. This representative height migrates $67 \mathrm{~m}$ up Griesgletscher during the period 1923-1991 and will reach the equilibrium line altitude (ELA) of the assumed balancealtitude curve at $486 \mathrm{~m}$ when the glacier is in a new steady-state for the 1961-1994 balance distribution.

Both climatic and geometric factors are important for the dynamic response of glaciers and ice caps. Cold/dry glaciers have a relatively small static sensitivity to a perturbation (Raper et al., 2000), but their much greater mass, especially in the form of arctic glaciers, means that 
Table 4

Model results for glacier precipitation, mass balance amplitude and temperature sensitivity for different area distributions, Griesgletscher, Switzerland. Representative height defined by Raper et al. (1996), modelled mass balance from Braithwaite and Zhang (2000) and area distributions from Funk et al. (1996)

\begin{tabular}{|c|c|c|c|c|c|c|}
\hline \multirow[t]{2}{*}{ Year } & \multicolumn{2}{|c|}{ Area distribution } & \multicolumn{4}{|l|}{ Model results } \\
\hline & $\begin{array}{l}\text { Glacier area } \\
\left(\mathrm{km}^{2}\right)\end{array}$ & $\begin{array}{l}\text { Representative } \\
\text { height }(\mathrm{m})\end{array}$ & $\begin{array}{l}\text { Glacier precipi- } \\
\text { tation }\left(\mathrm{m} \mathrm{a}^{-1}\right)\end{array}$ & $\begin{array}{l}\text { Mass balance } \\
\left(\mathrm{m} \mathrm{a}^{-1}\right)\end{array}$ & $\begin{array}{l}\text { MB amplitude } \\
\left(\mathrm{m} \mathrm{a}^{-1}\right)\end{array}$ & $\begin{array}{l}\Delta b / \Delta T \\
\left(\mathrm{~m} \mathrm{a}^{-1} \mathrm{deg}^{-1}\right)\end{array}$ \\
\hline 1923 & 7.86 & 612 & 1.79 & -0.51 & 1.57 & -0.69 \\
\hline 1961 & 6.69 & 587 & 1.82 & -0.40 & 1.54 & -0.68 \\
\hline 1979 & 6.34 & 560 & 1.85 & -0.27 & 1.50 & -0.66 \\
\hline 1986 & 6.25 & 560 & 1.85 & -0.27 & 1.50 & -0.66 \\
\hline 1991 & 6.19 & 545 & 1.86 & -0.21 & 1.49 & -0.63 \\
\hline Mean & 6.67 & & 1.83 & -0.33 & 1.52 & -0.66 \\
\hline
\end{tabular}

their long-term response to climate change may be greater than warm/wet glaciers. Geometric factors controlling the dynamic response include the maximum elevation, the altitudinal range and the area-altitude distribution (Raper et al., 1996) and these geometric factors depend in turn on the topographic features of the region.

\section{Work in progress}

Here we briefly discuss ongoing work at the University of Manchester, UK, and at the Alfred Wegener Institute for Polar and Marine Research, Germany, to improve future estimates of the glacier contribution to sea level change. We are creating a gridded glacierclimate model to calculate sea level changes that will occur as a result of changes in glacier mass balance. The model input will be climate changes for different regions and the output will be projections of changing glacier volume in the different regions.

The main limitation of mass balance modelling (Oerlemans, 1993; Braithwaite and Zhang, 1999) is the relative sparsity of balance-altitude datasets (Braithwaite, 2002) to calibrate models. Although we have now extended the work of Braithwaite and Zhang (1999) to 61 glaciers, we still doubt that the results are truly representative of conditions in various glacial regions. However, the scope of mass balance modelling can be enormously expanded by tuning the model to give zero mass balance at the estimated ELA of a glacier. The ELA can be estimated within a few decametres for thousands of glaciers all over the world using glacier altitudes listed in glacier inventories. For example, the median glacier altitude, dividing the glacier area into equal halves, is closely correlated with the balanced budget ELA (Braithwaite and Müller, 1980) and is a standard parameter of the WGI (Müller et al., 1977). Where the median altitude is not available, it can be estimated as the average of maximum and minimum glacier altitudes. We are exploiting this approach in a number of sub-projects: (a) A study of glacier-climate conditions at the ELA of glaciers based on field data from Ohmura et al. (1992) will be published. The main result is to show that the long-known association between accumulation and summer mean temperature at the ELA (Ohmura et al., 1992) can be explained in terms of a degree-day model with sinusoidal temperature variation throughout the year. The annual temperature range is identified as an important glacier-climate variable in agreement with Reeh (1991) and the degree-day factors for snowmelt are estimated for each of 67 glaciers in the dataset of Ohmura et al. (1992). The mean and standard deviation of the degree-day factor for melting snow is $3.6 \pm 1.1$ $\mathrm{mm} \mathrm{d}^{-1} \mathrm{~K}^{-1}$, which is in reasonable agreement with the values assumed by Braithwaite and Zhang $(1999,2000)$ although a little lower.

(b) The degree-day model, using the mean degree-day factor from (a), is applied to the estimated ELA altitude for $0.5^{\circ}$ grid squares in different regions. Seven glacial regions have been chosen for a pilot study: Axel Heiberg Island (55 grid squares), Svalbard (36 grid squares), Northern Scandinavian (47 grid squares), South Norway (29 grid squares), the Alps (43 grid squares), The Caucasus (28 grid squares) and New Zealand (22 grid squares). The Svalbard-Caucasus transect was chosen to cover the main glacier regions of Europe and the other two regions were added to extend results to dry-cold and warm-wet extremes. In all seven cases, the glacier inventory is of high quality allowing estimation of the ELA for many thousands of glaciers. Monthly mean temperature and annual temperature range are extrapolated to the estimated ELA from the gridded climatology of New et al. (1999) and the seasonal variation of precipitation is assumed to be the same as in the gridded climatology.

(c) The degree-model is applied to the estimated mean ELA for each $0.5^{\circ}$ grid square in the seven regions and a variety of glacier-climate variables at the ELA are calculated. These include accumulation and ablation, summer and annual mean temperatures, duration of melt season, vertical gradient of mass balance and mass balance sensitivity to temperature and precipitation 


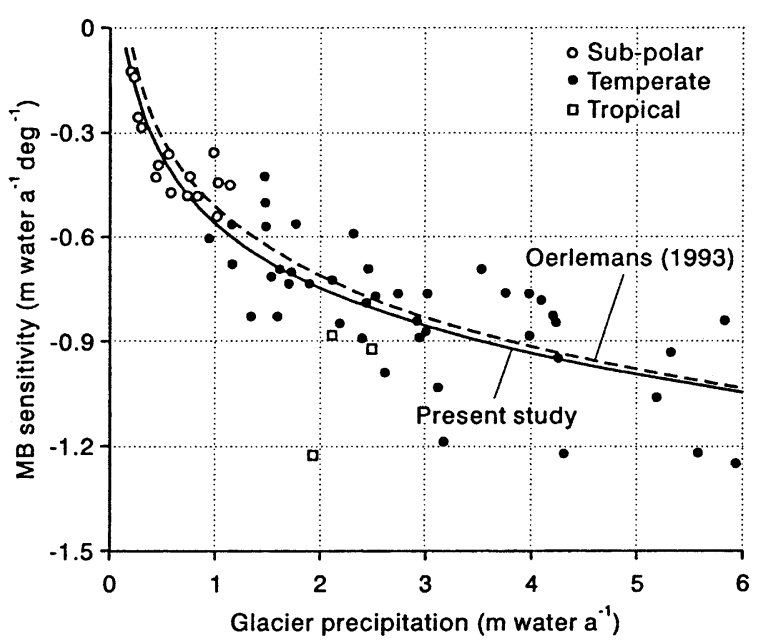

Fig. 3. Glacier precipitation versus gridded precipitation $\left(0.5^{\circ}\right.$ grid $)$ for seven different regions. Glacier precipitation is calculated for estimated mean ELA glacier altitude in each grid square by a degree-day model based on Braithwaite and Zhang (1999). Gridded precipitation is taken from the gridded climatology of New et al. (1999).

changes. The precipitation at the ELA is also calculated for each grid square and confirms the suspicion that glacier-level precipitation is considerably larger than the grid precipitation in New et al. (1999) for the seven glacier regions (Fig. 3). Efforts to downscale results from GCM outputs to glaciers must take account of this.

(d) The glacier geometry model (Raper et al., 2000) is extended to aggregates of glaciers, as opposed to single glaciers, to improve estimates of dynamic response. The approach is to model a distribution of simple glacier models for each grid cell with parameters reflecting the observed geometric characteristics of the glaciers in grid cell. The differing glacier altitude range, area and volume is then tracked by the simple geometric model as the climate changes.

In principle, the modelling described above can be applied to any grid square with adequate information on glacier altitudes and shape factors, e.g. as depicted in the WGI. After completing (a)-(d) for the seven glacier regions currently under study, the approach will be extended to as many other glacier regions as possible. For areas not covered by the WGI, it will be necessary to generalise the results of (a)-(d), possibly by scaling or similarity arguments. If there are any areas where there are too few data for any improved sea level assessment, they must be clearly identified as targets for future work.

First results of (a)-(d) suggest large variations of glacier-climate conditions within each region, especially in the form of gradients, as well as between regions. This suggests that our gridded approach may be an advance on the present "state of the art" (Church et al., 2001) of representing the 100 glacier regions, of varying size, as 100 points.

\section{Acknowledgements}

The work of both authors in 1996-1999 was supported by the Climate and Environment Programme, European Union (Grant number ENV4-CT95-0124) under grants to the University of Manchester and the University of East Anglia. Sarah Raper is now supported by the HGF Strategiefonds-Projekt 2000/13 (SEAL project) of the German Government. The gridded climatology data is supplied by the Climate Impacts LINK Project (UK Department of the Environment, Transport and the Regions contract no. EPG 1/1/96) on behalf of the Climatic Research Unit, University of East Anglia.

\section{References}

Armstrong, T., Roberts, B., Swithinbank, C., 1973. Illustrated Glossary of Snow and Ice. Scott Polar Research Institute, Cambridge, p. 59.

Bahr, D.B., Meier, M.F., Peckham, S., 1997. The physical basis of glacier volume area scaling. Journal of Geophysical Research 102, 20355-20362.

Braithwaite, R.J., 1980. Glacier energy balance and temperature: comments on a paper by Dr. M. Kuhn. Journal of Glaciology 25 (93), 501-503.

Braithwaite, R.J., 2002. Glacier mass balance: the first 50 years of international monitoring. Progress in Physical Geography 26 (1), 90-109.

Braithwaite, R.J., Müller, F., 1980. On the parameterization of glacier equilibrium line altitude. In: Proceedings of the Riederalp Workshop 1978-World Glacier Inventory, vol. 126. International Association of Hydrological Sciences Publication, pp. 263271.

Braithwaite, R.J., Zhang, Y., 1999. Modelling changes in glacier mass balance that may occur as a result of climate changes. Geografiska Annaler 81A (4), 489-496.

Braithwaite, R.J., Zhang, Y., 2000. Sensitivity of mass balance of five Swiss glaciers to temperature changes assessed by tuning a degreeday model. Journal of Glaciology 46 (152), 7-14.

Briggs, P.R., Cogley, J.G., 1996. Topographic bias in mesoscale precipitation networks. Journal of Climate 9, 205-218.

Church, J.A., Gregory, J.M., Huybrechts, P., Kuhn, M., Lambeck, K., Nhuan, M.T., Qin, D., Woodworth, P.L., 2001. Changes in sea level. In: Houghton, J.T., Ding, Y., Griggs, D.J., Noguer, M., van der Linden, P., Dai, X., Maskell, K., Johnson, C.I. (Eds.), Climate Change 2001: The Scientific Basis Contribution of Working Group I to the Third Assessment Report of the Intergovernmental Panel on Climate Change. Cambridge University Press, pp. 639693

Cogley, J.G., 1998. GGHYDRO Release 2.2. ftp://ftp.trentu.ca/pub/ gghyro. Accessed June 1998.

Cogley, J.G., Adams, W.P., 1998. Mass balance of glaciers other than the ice sheets. Journal of Glaciology 44 (147), 315-325.

Dyurgerov, M.B., 2002. Glacier mass balance and regime: data of measurements and analysis. Institute of Arctic and Alpine Research, Occasional Paper 55.

Dyurgerov, M.B., Meier, M.F., 1997. Mass balance of mountain and subpolar glaciers: a new global assessment for 1961-1990. Arctic and Alpine Research 29 (4), 379-391.

Dyurgerov, M.B., Meier, M.F., 2000. Twentieth century climate change: evidence from small glaciers. Proceedings of the National Academy of Sciences 97 (4), 1406-1411. 
Frei, C., Schär, C., 1998. A precipitation climatology of the Alps from high-resolution rain-gauge observations. International Journal of Climatology 18, 873-900.

Funk, M., Morelli, R., Stahel, W., 1996. Mass balance of Griesgletscher 1961-1995: different methods of determination. Z. Gletscherkd. Glazialgeol. 33 (1), 41-55.

GLIMS. 2000. Global Land Ice Measurements from Space (GLIMS): using the World's Glaciers to Monitor Climate Change. US Geological Survey, Flagstaff, Arizona, http://wwwflag.wr.usgs. gov/GLIMS/glimshome.html.

Gregory, J.M., Oerlemans, J., 1998. Simulated future sea-level rise due to glacier melt based on regionally and seasonally resolved temperature changes. Nature 391, 474-476.

Greuell, W., Böhm, R., 1998. 2 m temperatures along melting midlatitude glaciers, and implications for the sensitivity of the mass balance to variations in temperature. Journal of Glaciology 44 (146), 9-20.

Haeberli, W., Bösch, H., Scherler, K., Østrem, G., Wallén, C.C., 1989. World glacier inventory: status 1988. IAHS(ICSI) - UNEP UNESCO, Paris.

Hulme, M., 2000. MAGICC and SCENGEN (Version 2.4). Climatic Research Unit, University of East Anglia, http://www.cru.uea.ac. uk/ mikeh/software/MAGICC_SCENGEN.htm, Accessed July 2001.

Hulme, M., New, M., 1997. Dependence of large-scale precipitation climatologies on temporal and spatial sampling. Journal of Climate $10,1099-1113$.

Huybrechts, P., de Wolde, J., 1999. The dynamic response of the Greenland and Antarctic ice sheets to multiple-century climatic warming. Journal of Climate 12, 2169-2188.

IPCC. 2000. Data Distribution Centre, Intergovernmental Panel on Climate Change IPCC: Providing climate change and related scenarios for impacts assessments, Climatic Research Unit, University of East Anglia, http://ipcc-ddc.cru.uea.ac.uk/ Accessed July 2001.

Imbrie, J., Imbrie, K.P., 1979. Ice Ages: Solving the Mystery. Harvard University Press, Cambridge Mass, $224 \mathrm{pp}$.

Jóhannesson, T., 1997. The response of two Icelandic glaciers to climatic warming computed with a degree-day glacier mass-balance model coupled to a dynamic glacier model. Journal of Glaciology 43 (144), 321-327.

Jones, P.D., Osborn, T.J., Briffa, K.R., 1997. Estimating sampling errors in large-scale temperature averages. Journal of Climate 10, 2548-2568.

Meier, M.F., 1984. Contributions of small glaciers to global sea level. Science 226 (4681), 1419-1421.

Meier, M.F., 1993. Ice, climate, and sea level; do we know what is happening? In: Peltier, W.R. (Ed.), Ice in the Climate System. Springer-Verlag, Berlin and Heidelberg, pp. 141-160.

Meier, M.F., Bahr, D., 1996. Counting glaciers: use of scaling methods to estimate the number of size distribution of glaciers of the world. In: Colbeck, S.C. (Ed.), Glaciers, ice sheets and volcanoes: a tribute to Mark F, Meier. CRREL Special Report 96-27. US Army, Hanover, New Hampshire, pp. 89-94.

Müller, F., Caflisch T., Müller, G., 1977. Instructions for compilation and assemblage of data for a World Glacier Inventory. Temporary Technical Secretariat (TTS) for World Glacier Inventory. Department of Geography, Swiss Federal Institute of Technology, Zürich, p. 29.

New, M., Hulme, M., Jones, P., 1999. Representing twentieth century space-time climate variability. I. Development of a 1961-1990 mean monthly terrestrial climatology. Journal of Climate 12, 829856.
Oerlemans, J., 1993. Modelling of glacier mass balance. In: Peltier, W.R. (Ed.), Ice in the Climate System. Springer-Verlag, Berlin and Heidelberg, pp. 101-116.

Oerlemans, J., 2001. Glaciers and climate change. Lisse, A.A. Balkema, p. 148.

Oerlemans, J., Hoogendoorn, N.C., 1989. Mass-balance gradients and climatic change. Journal of Glaciology 35 (121), 399-405.

Oerlemans, J., Fortuin, J.P.F., 1992. Sensitivity of glaciers and small ice caps to Greenhouse warming. Science 258, 115-117.

Oerlemans, J., Anderson, B., Hubbard, A., Huybrechts, P., Jóhannesson, T., Knap, W.H., Schmeits, M., Stroeven, A.P., van de Wal, R.S.W., Wallinga, J., Zuo, Z., 1998. Modelling the response of glaciers to climate warming. Climate Dynamics 14, 267-274.

Ohmura, A., Kasser, P., Funk, M., 1992. Climate at the equilibrium line of glaciers. Journal of Glaciology 38 (130), 397-411.

Polar Research Board of the National Research Council. 1985. Glaciers, ice sheets, and sea level: effect of a $\mathrm{CO}_{2}$-induced climatic change. Report of a workshop held in Seattle, Washington, 13-15 September 1984, US Department of Energy Publication DOE/EV/ 60235-1.

Raper, S.C.B., Briffa, K.R., Wigley, T.M.L., 1996. Glacier change in northern Sweden from AD500: a simple geometric model of Storglaciären. Journal of Glaciology 42 (141), 341-351.

Raper, S.C.B., Brown, O., Braithwaite, R.J., 2000. A geometric glacier model for sea level change calculations. Journal of Glaciology 46 (154), 357-368.

Reeh, N., 1991. Parameterization of melt rate and surface temperature on the Greenland ice sheet. Polarforschung 59 (3), 113-128.

Scherler, K., 1983. Guidelines for preliminary glacier inventories. Temporary Technical Secretariat (TTS) for World Glacier Inventory. Department of Geography, Swiss Federal Institute of Technology, Zürich, p. 16.

Schneeberger, C., Albrecht, O., Blatter, H., Wild, M., Hock, R., 2001. Modelling the response of glaciers to a doubling in atmospheric $\mathrm{CO}_{2}$ : a case study of Storglaciären, northern Sweden. Climate Dynamics 17, 825-834.

Van de Wal, R.S.W., Wild, M., 2001. Modelling the response of glaciers to climate change by applying the volume-area scaling in combination with a high resolution GCM. Climate Dynamics 18 , 359-366.

Warrick, R.A., Oerlemans, J., 1990. Sea level rise. In: Houghton, J.T., Jenkins, G.J., Ephraums, J.J. (Eds.), Climate Change-The IPCC Scientific Assessment. Cambridge University Press, Cambridge, pp. $358-405$.

Warrick, R.A., Le Provost, C., Meier, M.F., Oerlemans, J., Woodworth, P.L., 1996. Changes in sea level. In: Houghton, J.T., Meira Filho, L.G., Callander, B.A., Harris, N., Kattenberg, A., Maskell, K. (Eds.), Climate change 1995-The science of climate change. Cambridge University Press, Cambridge, pp. 257-281.

Weidick, A., Morris, E., 1998. Local glaciers surrounding the continental ice sheets. In: Haeberli, W., Hoelzle, M., Suter, S. (Eds.), Into the second century of worldwide glacier monitoring-prospects and strategies. UNESCO, Paris, pp. 197205.

WGMS. 2000. The World glacier inventory. World Glacier Monitoring System, University of Zürich, Zürich, Switzerland, http:// nsidc.org/NOAA/wgms_inventory/ Accessed July 2001.

Yang, D., Ishia, S., Goodison, B.E., Gunther, T., 1999. Bias correction of daily precipitation measurements for Greenland. Journal of Geophysical Research 104 (6), 171-176, 181.

Zuo, Z., Oerlemans, J., 1997. Contribution of glacier melt to sea-level rise since AD 1865: a regionally differentiated calculation. Climate Dynamics 13, 835-845. 